\title{
REPRESENTASI BUDAYA PATRIARKI PADA KOMUNITAS GEREJA KRISTEN PROTESTAN DI BALI (GKPB)
}

\author{
Made Narawati \\ Mahasiswa Program Magister Kajian Budaya Universitas Udayana \\ Email: madenarawati@yahoo.co.id
}

\begin{abstract}
ABSTRAK
Gereja Kristen Protestan di Bali (GKPB) adalah Gereja Protestan terbesar di Bali. Berdasarkan data, anggota GKPB laki-laki dan perempuan mulai berimbang yaitu 6.560 Jiwa (50,95\%) berbanding 6.315 Jiwa (49,04\%). Namun secara kuantitas kepemimpinan strategis, Personil Majelis Sinode Lengkap (MSL-GKPB), periode 2012-2016, yang berjumlah 31 orang; laki-laki berjumlah 29, sedangkan perempuan hanya 2 orang. Periode 2016-2020 jumlah Majelis Sinode Lengkap (MSL) : 30 orang yang terdiri dari 27 Laki-laki ( 90\%) dan 3 Perempuan ( 10\%). Majelis Sinode Lengkap (MSL) diberikan otoritas sebagai pengambil keputusan dan kebijakan di lingkungan GKPB. Jabatan strategis tersebut ditempati oleh sebagian besar laki-laki baik pendeta maupun non pendeta. Budaya patriarki sangat kuat dalam penentun jabatan strategis di GKPB dengan mengacu kepada Tata Gereja Tahun 2014 tentang keanggotaan Pasal 107 ayat 1, 8 (delapan) orang yang dipilih dalam sidang sinode harus terdiri sekurangnya 2 orang unsur perempuan dan 1 orang unsur pemuda. Data membuktikan bahwa pemegang jabatan Sinode, Departemen, Yayasan, Ketua-ketua Wilayah, dan di jemaat-jemaat sebagian besar dipegang oleh laki-laki. Melihat realita ini kuantitas pejabat di dominasi oleh laki-laki dan kebijakan untuk menentukan jabatan tersebut merupakan representasi budaya patriarki yang kuat, laki-laki adalah pemimpin, perempuan belum ada tempatnya. Perempuan juga merasa nyaman dengan posisinya dan mungkin budaya patriarki sudah terinternalisasi di GKPB.

Dengan metode kualitatif dan menggunakan Teori Feminisme Liberal, Relasi Kekuasaan-Pengetahuan dan Dekonstruksi dapat mengungkap Representasi Budaya Patriarki pada Komunitas Gereja Kristen Protestan di Bali (GKPB). Apa bentuk-bentuk budaya patriarki, mengapa terjadi dan bagaimana implikasi budaya patriarki pada komunitas GKPB. Sehingga dapat memberikan perspektif kepemimpinan feminis yang adil gender.
\end{abstract}

Kata Kunci: Representasi, Patriarki, GKPB

\section{PENDAHULUAN}

Cultures studies adalah sebuah disiplin ilmu yang menyatakan keberpihakan terhadap kaum lemah, ter-subordinasi dan termarginal atau terpinggirkan. Cultural studies adalah studi mengenai praktik penandaan pada suatu fenomena. Kuasa yang dipahami adalah kuasa dalam konteks yang luas dari yang terlembagakan dan bersifat makro sampai yang personal, seharihari dan mikro, bahkan kadang-kadang termanifestasikan dalam hal-hal yang dianggap remeh, sepele, "tidak penting" dalam kehidupan banyak orang (Budiawan, 2015 : ix-x). Kesalahpahaman yang harus diluruskan yaitu gender dianggap hanya masalah perempuan, gender hanya disamakan dengan seks dan kodrat. Gender sering berhenti pada sebuah konsep jenis kelamin laki-laki dan perempuan, tetapi bagaimana gender itu dipahami dalam proses kontruksi sosial dimana kesetaraan antara laki-laki dan perempuan memiliki kesamaan kesempatan, hak dan partisipasi, peran dan fungsi yang sama dalam dunia pembangunan masyarakat.

Indonesia adalah bangsa yang menjunjung tinggi Hak Asasi Manusia (HAM). UndangUndang Dasar Tahun 1945 Pasal 28D ayat (1) berbunyi, "setiap orang berhak atas pengakuan, jaminan, perlindungan, dan kepastian hukum yang adil serta perlakuan perlakuan yang sama di hadapan hukum". Pasal 28D ayat (3) UndangUndang Dasar (UUD) Tahun 1945 amandemen kedua mengamanatkan "setiap warga negara berhak memperoleh kesempatan yang sama dalam pemerintahan". Pasal $28 \mathrm{H}$ ayat (2) yang berbunyi, "setiap orang berhak mendapat kemudahan dan perlakuan khusus untuk memperoleh kesempatan dan manfaat yang sama guna mencapai persamaan dan keadilan" ( Tim Grasindo, 2017:81-83). UUD 1945 \& Amandemennya untuk Pelajar dan Umum.

Sudah jelas tercantum dalam UndangUndang Dasar (UUD) Tahun 1945 bahwa perempuan berhak mendapatkan perlakuan yang 
sama dalam pemerintahan. Artinya perempuan yang sering dianggap lemah berhak menjadi pemimpin negara. Bukan hanya itu, terdapat pula penetapan kuota $30 \%$ perempuan di parlemen melalui Undang-Undang Nomor 8 Tahun 2012 tentang Pemilihan Umum Anggota Dewan Perwakilan Rakyat, Dewan Perwakilan Daerah, dan Dewan Perwakilan Rakyat Daerah (Arina Dina Hanifa www.qureta.com)

Bagi orang yang menganut agama Kristen, Alkitab merupakan sumber ajaran, sumber moral dan sumber inspirasi. Dalam Perjanjian Lama, terdapat tekanan antara dinamika Allah yang membebaskan umat-Nya dan memandang kaum laki-laki dan perempuan sederajat. Kejadian 1:27 “ Maka Allah menciptakan manusia itu menurut gambar-Nya, menurut gambar Allah di citakan-Nya dia, lakilaki dan perempuan diciptakan-Nya mereka". Maka jadilah laki-laki dan perempuan, diciptakan setara satu sama lain, menurut gambar Allah. Selama kehidupan-Nya Yesus telah memperlihatkan sikap yang terbuka terhadap kaum wanita yang diciptakan serupa dengan gambar Allah, sama seperti kaum laki-laki. Rasul Paulus menangkap sikap Yesus yang terbuka dalam Galatia 3:28: " Dalam hal ini tidak ada orang Yahudi atau orang Yunani, tidak ada hamba atau orang merdeka, tidak ada laki-laki atau perempuan, karena kamu semua adalah satu dalam Kristus Yesus" Dimana Ia menyaksikan kemerdekaan umat Allah dari pembatasan budaya.

Ternyata masyarakat di dalam gereja yang telah terbentuk pola pikirnya dalam budaya patriarki menganggap bahwa mengeluarkan pendapat, bertanya, dan berperan sebagai pemimpin, pengambil keputusan bukan merupakan peranan perempuan tetapi laki-laki. Gereja Kristen Protestan di Bali (GKPB) adalah Gereja Protestan terbesar di Bali. Dalam penjelasan Tata Gereja Tahun 2014 tentang keanggotaan Pasal 107 ayat 1, 8 (delapan) orang yang dipilih dalam sidang sinode harus terdiri sekurangnya 2 orang unsur perempuan dan 1 orang unsur pemuda. Diharapkan ada unsur perempuan, tetapi kenyataannya perempuan hanya menjadi pelengkap untuk memenuhi syarat "unsur perempuan". Pemimpin adalah 'orangnya', baik laki-laki maupun perempuan. Gereja Kristen Protestan di Bali (kemudian disingkat GKPB), pada jabatan strategis,

yakni Majelis Sinode Lengkap (kemudian disingkat MSL). Jabatan ini, diberikan otoritas sebagai pengambil keputusan dan kebijakan di lingkungan GKPB. Berdasarkan data dari Made Kertiyana, kepala bidang administrasi dan kepegawaian GKPB, di mana anggota GKPB lakilaki dan perempuan mulai berimbang yaitu 6.560 Jiwa $(50,95 \%)$ berbanding 6.315 Jiwa $(49,04 \%)$. Jumlah Majelis Sinode Lengkap (MSL) : 30 orang yang terdiri dari 27 Laki-laki ( 90\%) dan 3 Perempuan ( $10 \%$ ), Kabid : 10 orang terdiri dari 6 Laki-Laki (60\%) dan 2 Perempuan (40\%), Pendeta Emeritus : 35 Orang terdiri dari 32 Lakilaki (91\%) dan 3 Perempuan ( 9\%), Pendeta aktif: 63 orang terdiri dari 39 Laki-laki (62\%) dan 24 Perempuan (38\%), Vikaris :19 Orang terdiri dari 9 Laki-laki (47\%) dan 10 Perempuan (53\%). Jumlah pendeta aktif dan vikaris terdiri dari 48 Laki-laki (67\%) dan 34 Perempuan (33\%). Dari data ini menyatakan jumlah pendeta dan vikaris perempuan sangat banyak di GKPB. Pemimpin adalah 'orangnya', baik laki-laki maupun perempuan. Gereja Kristen Protestan di Bali (GKPB), pada jabatan strategis, yakni Majelis Sinode Lengkap (MSL). Jabatan ini, diberikan otoritas sebagai pengambil keputusan dan kebijakan di lingkungan GKPB. Secara kuantitas, sampai saat ini (periode 2016-2020) jabatan tersebut ditempati oleh sebagian besar laki-laki ( $90 \%$, baik pendeta maupun non pendeta). Melihat realita ini, dapat disimpulkan bahwa Jemaatjemaat di GKPB yang di wakili oleh Majelis Jemaat dalam sidang sinode sangat dipengaruhi oleh budaya patriarki yang kuat, laki-laki dalah pemimpin, perempuan belum ada tempatnya. Data membuktikan bahwa pemegang jabatan strategis Sinode sebagian besar dipegang oleh laki-laki.

Budaya patriarki sudah terinternalisasi pada komunitas GKPB yang mengakibatkan para perempuan diduga terkotopsi dengan budaya tersebut. Para perempuan dan pendeta perempuan GKPB merasa tidak terganggu dan menganggap hal biasa jikalau yang berhak memimpin adalah kaum laki-laki. Menurut ibu Wid, "kenyataan di atas disebabkan gereja-gereja di GKPB yang diwakili oleh majelis jemaat/presbiter, mengusulkan sedikit sekali nama perempuan pendeta sebagai bakal calon anggota MSL kepada panitia verifikasi untuk kemudian dipilih oleh peserta sidang sinode. Buktinya hanya ada satu perempuan pendeta yang diusulkan oleh beberapa gereja sebagai calon sekretaris umum yakni saya sendiri (ibu Wid), dan 'bersaing' dengan lima orang pendeta laki-laki", demikian tutur beliau ( Lawalata, 2014:8) 
Demikian juga dalam beberapa peraturan dan kebijakan GKPB terkesan ada diskriminasi terhadap kaum perempuan. Dalam penjelasan Tata Gereja Tahun 2014 tentang keanggotaan Pasal 107 ayat 1,8 (delapan) orang yang dipilih dalam sidang sinode harus terdiri sekurangnya 2 orang unsur perempuan dan 1 orang unsur pemuda.

Berdasarkan latar belakang masalah di atas, peneliti ingin menggali lebih dalam tentang Representasi Budaya Patriarki Pada Komunitas Kristen Protestan di Bali (GKPB). Bagaimana bentuk, mengapa terjadinya dan implikasi Budaya Patriarki pada komunitas GKPB? Penelitian ini bermanfaat untuk memberikan perspektif kepemimpinan feminis yang adil gender sebagai bagian dari teologi feminis bagi gereja-gereja dalam memahami kepemimpinan perempuan pendeta pada jabatan strategis di sinode-sinode gereja.

\section{METODE}

Penelitian ini memiliki landasan keilmuwan yaitu Kajian Budaya (Cultural Studies) dengan pendekatan kualitatif. Penelitian kualitatif mendeskripsikan fakta dan fenomena sosial, kemudian menganalisa dan memahami perilaku atau proses sosial masyarakat yang terpola. Penelitian kualitatif menekankan sifat realita yang terbangun secara rasional karena ada hubungan erat antara peneliti dengan subjek yang diteliti. Penelitian kualitatif mementingkan sifat penyelidikan sarat nilai dengan mencari jawaban atas pertanyaan yang menyoroti bagaimana munculnya pengalaman sosial sekaligus berusaha menelusuri proses dan memahami perolehan makna (Denzin dan Lincoln, 2009:6).

Penelitian menggunakan metode kualitatif dilaksanakan di kantor Sinode GKPB, Jln. Raya Kapal, nomor 20, Mengwi, Badung, Bali dan di beberapa tempat tugas pelayanan para pendeta (gedung gereja, pastori/rumah pendeta) dan rumah-rumah majelis jemaat, di seputar Bali. Teknik Pengumpulan data dalam penelitian ini meliputi observasi, wawancara dan informan ditentukan berdasarkan purposive sampling, dimana informan kuncinya ialah MSH (Majelis Sinode Harian), MSL (Majelis Sinode Lengkap), Pejabat di Lembaga dan Yayasan, dan Pendeta, Majelis Jemaat dan Jemaat GKPB. Instrumen penelitian antara lain pedoman wawancara, $\mathrm{hp}$, alat tulis, dan buku catatan. Analisis data dalam penelitian ini meliputi tiga kegiatan yang terjadi hampir secara bersamaan, yaitu reduksi data, penyajian data dan penarikan simpulan. Reduksi data dipahami sebagai bentuk analisis yang menajamkan, menggolongkan, mengarahkan, membuang yang tidak perlu dan mengorganisasikan data sehingga simpulansimpulan final dapat ditarik dan diverifikasikan, hingga data dapat disajikan secara naratif.

\section{PEMBAHASAN}

Representasi menurut kamus besar bahasa Indonesia (KBBI) adalah perbuatan mewakili, keadaan diwakili, apa yang mewakili, perwakilan (kbbi.web.id). Representasi juga merupakan sebuah proses atau praktek penting yang akan melahirkan sebuah kebudayaan. Representasi budaya patriarki sangat mungkin terjadi alami karena adanya sebuah proses yang berulang secara terus menerus tanpa disadari menjadi kebiasaan (pengertian menurutparaahli.net)

Makna yang bisa diterima akal sehat tentang konsep representasi adalah sejumlah proses dimana praktik-praktik penandaan tampaknya menggambarkan objek atau praktik yang terjadi di dunia nyata. Representasi dengan demikian adalah sebuah tindakan simbolisme yang mencerminkan dunia objek yang independen. Akan tetapi bagi kajian budaya, representasi bukan hanya merefleksikan dalam bentuk simbolis sesuatu yang eksis di dunia objek yang independen, melainkan representasi itu sendiri bersifat konstitutif terhadap makna yang mau disampaikan atau diperjuangkan. Representasi dengan demikian tidak melibatkan korespondensi antara tanda dan objek melainkan menciptakan dampak representasional dari realisme. Di sini representasi dipahami sebagai sebagai sesuatu yang secara intrinsik terkait dengan persoalan kekuasaan lewat proses seleksi dan organisasi, yang tidak bisa disangkal lagi merupakan bagian tak terpisahkan dari pembentukan representasi itu sendiri. Kekuatan representasi terletak dalam kemampuannya menghidupkan sejumlah pengetahuan dan mematikan sejumlah pandangan yang lain ( Barker, 2014:255).

Pada kehidupan suatu negara jika relasi antara perempuan dan laki-laki masih bersifat asimetris maka bisa dikatakan masyarakatnya masih berada dalam budaya patriarki. Oleh Marla Mies mengatakan budaya ini dianggap sebagai suatu sistem nilai yang menempatkan laki-laki 
pada tempat yang lebih tinggi dari pada kaum perempuan, dan keadaan tersebut merembes ke dalam berbagai dimensi yang ada dalam masyarakat, sehingga bukan sesuatu yang berlebihan bila dalam system budaya semacam itu kaum laki-laki berada pada pihak yang mendominasi, sementara kaum perempuan berada dipihak yang mengalami penundukan ( Mies, 1986:37).

Gereja Kristen Protestan di Bali (GKPB) merupakan Gereja Protestan terbesar di Bali dan hanya ada di Pulau Bali, terbentuk pada tanggal 11 November 1931 yang ditandai dengan dibaptiskannya 12 orang Bali di Sungai Yeh Poh, Dalung Kuta Badung Bali. Gereja Kristen Protestan di Bali (GKPB) berada di seluruh kabupaten dan kota di Provinsi Bali terdiri dari 67 Gereja dan 17 Balai Pembinaan Iman (BPI) dengan warga jemaat berjumlah 3.822 Kepala Keluarga (KK) 12.875 jiwa.

Selain jabatan gerejawi seperti Bishop, Pendeta, dan Majelis Jemaat, GKPB memberikan jabatan organisasi atau struktural pada lembagalembaga dan lembaga GKPB. Untuk Majelis Sinode Harian (MSH) dan Majelis Sinode Lengkap (MSL) di pilih dalam Sidang Sinode sedangkan pejabat di Lembaga dan Departemen di pilih dalam sidang MSL periode jabatan setiap empat tahun.

GKPB terdiri dari sekretariat kantor sinode, tiga departemen yaitu departemen persekutuan dan pembinaan GKPB, departemen kesaksian dan pengembangan GKPB dan departemen pelayanan dan pemberdayaan ekonomi masyarakat GKPB (Yasasan Maha Bhoga Marga). Dua Lembaga GKPB yaitu Yayasan Dhyana Pura dan PT. BPR Maha Bhoga Marga.

Sidang tertinggi GKPB disebut Sinode GKPB, setiap dua tahun sekali membahas evaluasi program dan setiap empat tahun sekali disebut siding pemilihan. Dalam sidang dihadiri oleh pendeta dan mejelis jemaat sebagai perwakilan dari masing-masing jemaat GKPB seluruh Bali.

Bentuk-bentuk Representasi budaya Patriarki pada komunitas GKPB. Yang pertama, paradigma patriarki sudah terinternalisasi di GKPB. Memperhatikan daftar hadir utusan-utusan sidang Sinode laki-laki dan perempuan, 70\% laki laki dan $30 \%$ perempuan. Para perempuan dan pendeta perempuan tidak merasa terganggu dan sudah terkotopsi dengan budaya patriarki tersebut.
Dalam masyarakat patriarki, laki-laki sering berkuasa atas semua anggota masyarakat yang lain (perempuan) dan mempertahankan kuasa sebagai milik yang "sah". Pandangan androsentris (andros=laki-laki dan sentris=berhubungan dengan inti) kemudian menentukan budaya, yakni segala peristiwa dilihat dari sudut pandang lakilaki. Menurut Luh Debora Murthy (salah satu Sekretaris Bidang yang mengurusi soal Perlindungan Perempuan dan Anak di GKPB) hal ini menjadi sumber ketidakadilan bagi perempuan di Bali seperti diskriminasi di dalam keluarga, tempat kerja, masyarakat, pemerintah dan peradilan bahkan di tempat ibadah yang pada akhirnya menimbulkan kerugian bagi kaum perempuan karena dinilai tidak sanggup dalam hal memimpin. Walaupun demikian, perempuan Bali (khususnya dalam masyarakat Hindu) telah memerankan peran yang sangat penting seperti dalam ranah keagamaan sebagai seorang rohaniawati yang dikenal dengan istilah pedande istri dan pada jabatan-jabatan kepemerintahan. Pengaruh budaya patriarkal sangat kuat mempengaruhi hal tersebut, pemimpin dominan laki-laki, kemudian menjadi sesuatu yang membudaya, sehingga perempuan merasa nyaman, menjadi pasif, tidak merasa penting/perlu untuk menduduki kursi kepemimpinan yang sangat mungkin diraihnya. Budaya patriarki yang dianut masyarakat Bali, dan beberapa teologi gereja/GKPB serta interpretasi jemaat atas beberapa teks Kitab Suci yang patriarki, mengakibatkan posisi dan peran perempuan menjadi tidak setara dengan laki-laki. Kepemimpinan, khususnya pada jabatan strategis sinode menjadi dominan laki-laki dengan gaya maskulin. Hal ini tentu melahirkan ketidakadilan gender di dalam gereja sebagaimana yang ditegaskan oleh Singgih. Menurut Singgih, ketidakadilan gender menjadi salah satu konteks di Indonesia, termasuk di dalam gereja. Menyadari konteks tersebut, muncul berbagai upaya yang dilakukan oleh gereja, salah satunya oleh aliran feminis termasuk para teolog feminis, dan oleh GKPB (Justus Abraham Lawalata dalam perempuan pendeta dan jabatan strategis (Studi tentang Kepemimpinan Perempuan di Gereja Kristen Protestan di Bali dalam Perspektif Adil Gender), 2014:8-10).

Yang kedua, bentuk representasi adalah kebijakan GKPB. GKPB dalam menjalankan kehidupan bergereja dan berorganisasi dalam kelembagan di tuntun oleh Tata Gereja GKPB. 
Beberapa peraturan dan kebijakan GKPB terkesan ada diskriminasi terhadap kaum perempuan. Dalam penjelasan Tata Gereja Tahun 2014 tentang keanggotaan Pasal 107 ayat 1, 8 (delapan) orang yang dipilih dalam sidang sinode harus terdiri sekurangnya 2 orang unsur perempuan dan 1 orang unsur pemuda. Dalam peraturan Gereja Kristen Protestan di Bali Nomor 07 tentang penyelenggaraan persidangan sinode, pasal 3. 2 tentang ketentuan utusan Jemaat dan Balai Pembinaan Iman, point 2.2 Bagi jemaat yang utusannya lebih dari satu orang supaya mengutus unsur wanita. Peraturan Gereja Kristen Protestan di Bali Nomor 06 tentang uraian tugas-tugas jabatan gerejawi dan tata cara pelaksanaan pemilihan majelis jemaat. Pasal 13 Prosedur Pemilihan Majelis Jemaat no 3 Rasio minimal Majelis Jemaat perempuan sekurang-kurangnya $30 \%$ dari jumlah Majelis Jemaat. (Tata Gereja GKPB, 2014).

Yang ketiga adalah Dominasi Laki-Laki dalam jabatan GKPB. Persoalan gender juga terjadi dalam kehidupan bergereja. Gereja Kristen Protestan di Bali (GKPB). Berdasarkan data dari Made Kertiyana, kepala bidang administrasi dan kepegawaian GKPB, di mana anggota GKPB lakilaki dan perempuan mulai berimbang yaitu 6.560 Jiwa (50,95\%) berbanding 6.315 Jiwa (49,04\%). Jumlah Majelis Sinode Lengkap (MSL) periode 2016-2020: 30 orang yang terdiri dari 27 Laki-laki ( 90\%) dan 3 Perempuan ( $10 \%$ ). Melihat realita ini, dapat disimpulkan bahwa Jemaat-jemaat di GKPB yang di wakili oleh Majelis Jemaat dalam sidang sinode sangat dipengaruhi oleh budaya patriarki yang kuat, laki-laki dalah pemimpin, perempuan belum ada tempatnya. Data membuktikan bahwa pemegang jabatan strategis Sinode sebagian besar dipegang oleh laki-laki.

Terkait dengan jabatan strategis sinode GKPB, bahwa perempun pendeta belum meraih kursi itu. Dalam kompetisi empat tahunan, perempuan pendeta belum mendapat kepercayaan. Dengan melihat pada jumlah calon yang sangat sedikit dari kalangan perempuan pendeta di jabatan strategis serta suara yang mereka peroleh, hal ini mengindikasikan bahwa ada persoalan. Artinya jemaat yang diwakilkan oleh majelis/presbiter memandang lemah dalam kaitan dengan kepemimpinan strategis untuk seorang perempuan, walaupun mereka sudah menunjukkan kemampuannya di jemaat. Secara faktual, cukup kompleks alasan sehingga perempuan pendeta sulit meraih jabatan strategis.
Faktor penyebab termarginalnya para perempuan dan pendeta perempuan dalam jabatan di Gereja Kristen Protestan di Bali (GKPB) sebagai berikut: pertama, ideologi patriarki yaitu dari budaya patriarkal yang masih kuat di Bali termasuk ke dalam gereja. Pemahaman inilah seharusnya didekonstruksi digantikan dengan paradigma yang baru. Medekonstruksi berarti mengambil, mengubah, (undo), agar dapat menemukan dan menunjukkan asumsi-asumsi yang ada di belakang teks. Secara khusus, dekonstruksi melibatkan upaya penanggalan konsep oposisi biner yang bersifat hirarkis seperti lelaki/perempuan, hitam/putih, penampakan/kenyataan, alam/budaya, akal budo/kegilaan, dan seterusnya, yang semakin mengukuhkan status serta kekuasaan dari pelbagai klaim kebenaran dengan cara menyingkirkan dan menurunkan nilai bagian "yang lebih rendah" dari pasangan oposisi biner tersebut ( Barker, 2014:6970). Penyelenggaraan kekuasaan terus menerus akan menciptakan entitas pengetahuan, begitu pun sebaliknya penyelenggaraan pengetahuan akan menimbulkan efek kekuasaan (Eriyanto, 2003: 65). Relasi kekuasaan dan pengetahuan dalam penentuan jabatan strategis GKPB dimulai dari kekuatan kuasa patriakhi dan senioritas pendeta laki-laki. Pengetahuan ideologi patriarki membawa kekuasaan turun temurun dari generasi ke generasi. Artinya fisik perempuan yang dipandang lebih lemah dari laki-laki, kemudian kodrat perempuan (seperti mengandung, melahirkan dan marawat bayi/menyusui, dll.) sebagai kendala bagi perempuan pendeta. Persoalan geografis wilayah pelayanan yang lebih luas di jabatan strategis sinode ketimbang di jemaat sebagai pendeta/ketua majelis jemaat. Melihat wilayah atau cakupan tugas pada jabatan strategis sinode cukup berat bagi seorang perempuan pendeta karena dipandang lemah secara fisik dan kodrat sebagai seorang ibu serta tugas domestik yang menyita waktu dan tenaga. Kondisi seperti ini tentu sangat mengganggu tugas sebagai anggota MSL, karena itu perempuan pendeta sulit mendapat dukungan untuk duduk di jabatan strategis sinode. Kedua, mengenai politik laki-laki yang dapat dilihat dalam beberapa hal. tentang: senioritas dan kuantitas pendeta laki-laki sebagai yang mayoritas sampai saat ini di GKPB. Kemudian, soal kondisi 'nyaman' kepemimpinan laki-laki. Artinya cukup banyak pendeta laki-laki merasa nyaman dan 'beruntung' dalam konteks dominasi kepemimpinan di jabatan strategis. 
Karena itu banyak upaya dilakukan mereka agar tetap menduduki jabatan tersebut dengan mencari dukungan suara/massa, dan hal tersebut tidak dilakukan oleh perempuan pendeta. Ketiga, kurangnya kesadaran gender di kalangan perempuan pendeta sebagai kendala dari dalam diri perempuan. Hal ini terlihat dari pendapat yang sering dikemukakan perempuan pendeta, bahwa pendeta laki-laki lebih kuat dan lebih berani dalam pengambilan keputusan, sedangkan perempuan pendeta tidak berani dan kurang tegas untuk hal tersebut. Oleh karena itu, perempuan pendeta sering ragu-ragu jika diberi kesempatan bahkan menolak diri untuk dicalonkan sebagai anggota MSL. Pada akhirnya banyak perempuan pendeta tidak mendukung pencalonan perempuan pendeta.Itu artinya hal ini dapat menunjukan adanya ketidaksadaran gender dari perempuan pendeta sendiri walaupun bisa juga merupakan dampak dari budaya patriarkal yang tidak ramah dengan kepemimpinan perempuan.

Implikasi Budaya Patriarki di GKPB, yaitu yang pertama, Resistensi simbolik dari kaum perempuan. Sebenarnya para perempuan ingin duduk dalam jabatan strategis dan memiliki kemampuan dalam jabatan tersebut tetapi sedikitnya peluang dan kesempatan. Dan para perempuan tidak mau bicara dan menyampaikan keinginan tersebut dalam forum tertentu. Perempuan terkotopsi dan membuat pertemuanpertemuan pendeta perempuan untuk mengisi dan memajukan diri dari segi ilmu dan pendidikan. Yang kedua, Hegemoni Terhadap Perempuan. Bagi Gramsci, hegemoni mengimplikasikan sebuah situasi dimana "blok historis" dari kelas yang berkuasa melakukan otoritas sosial dan kepemimpinannya terhadap kelas-kelas yang berada di bawahnya (sub-ordinat) lewat sebuah kombinasi kekuatan dan lebih penting lagi persetujuan (Barker, 2014:119). Kepemimpinan yang di dominasi kaum laki-laki tanpa terasa menghegemoni kaum perempuan. Kaum laki-laki sebagai kelas berkuasa menghegemoni kaum perempuan sebagai kaum lemah secara historis. Kepemimpinan yang terpilih menuntut persetujuan-persetujuan dari kaum perempuan dan dianggap sebagai hal yang biasa saja. Para perempuan tunduk kepada otoritas laki-laki tanpa beban dan rasa terpaksa. Perempuan harus mempersiapkan diri agar mereka bisa bersaing di dunia dalam kerangka "persaingan bebas" dan punya kedudukan setara dengan lelaki Akar teori ini bertumpu pada kebebasan dan kesetaraaan rasionalitas. Perempuan adalah makhluk rasional, kemampuannya sama dengan laki-laki, sehingga harus diberi hak yang sama juga dengan laki-laki. Permasalahannya terletak pada produk kebijakan negara yang bias gender (ekookdamezs.blogspot.com). Yang ketiga, Pergeseran Nilai Religius ke Hedonisme. Religius adalah sikap dan perilaku yang patuh dalam melaksanakan ajaran agama yang dianutnya, toleran terhadap pelaksanaan ibadah agama lain, dan hidup rukun dengan pemeluk agama lain (Suparlan, 2010 ). Hedonisme adalah pandangan hidup yang menganggap bahwa orang akan menjadi bahagia dengan mencari kebahagiaan sebanyak mungkin dan sedapat mungkin menghindari perasaan-perasaan yang menyakitkan (Wikipedia.org). Kehadiran gereja berdasarkan Kitab Suci yaitu Alkitab, menjadi dasar gereja untuk berkarya di tengah dunia. Gereja menerapkan ajaran-ajaran kebenaran, membangun toleransi dan kerukunan. Seiring perkembangan zaman kebutuhan manusia bukan religius lagi yang utama dan terpenting, tetapi nilai kenyamanan hidup. Pengaruh hedonisme membuat gereja bergeser dari dasar Alkitabiah dengan finansial dan materialistik. Jabatan yang tinggi dikejar untuk mencukupi kebutuhan hidup, karena penghasilan yang menggiurkan. Seperti ucapan seorang istri pejabat tertinggi GKPB "setelah jabatan ini, harus mencari jabatan yang lebih tinggi, karena kalau turun menjadi pendeta biasa tidak akan mencukupi kebutuhan" (Percakapan lisan dengan ES).

\section{SIMPULAN DAN SARAN}

\section{Simpulan}

Bentuk budaya patriarki, yang pertama yaitu paradigma patriarki sudah terinternalisasi di GKPB dari jemaat sampai kepada pimpinan gereja. Yang kedua kebijakan-kebijakan dalam tata gereja yang merupakan dasar GKPB berorganisasi dan berkarya terkesan memarginalkan quota perempuan. Yang ketiga dominasi kaum laki-laki dalam menduduki jabatan GKPB.

Faktor penyebab terjadinya budaya patriarki di GKPB yaitu yang pertama, ideologi patriarki sangat kuat di GKPB, menjadi pengetahuan dan dianggap kebenaran. Kedua, mengenai politik laki-laki mendominasi kepemimpinan di jabatan strategis. Karena itu banyak upaya dilakukan mereka agar tetap 
menduduki jabatan tersebut dengan mencari dukungan suara/massa, dan hal tersebut tidak dilakukan oleh perempuan pendeta. Ketiga, kurangnya kesadaran gender di kalangan perempuan pendeta sebagai kendala dari dalam diri perempuan.

Implikasi Budaya Patriarki di GKPB, yaitu yang pertama, Resistensi simbolik dari kaum perempuan. Yang kedua, Hegemoni Terhadap Perempuan. Yang ketiga, Pergeseran Nilai Religius ke Hedonisme. Pengaruh hedonisme membuat gereja bergeser dari dasar Alkitabiah dengan finansial dan materialistik. Jabatan yang tinggi dikejar untuk mencukupi kebutuhan hidup, karena penghasilan yang menggiurkan.

Dari kesimpulan di atas, penulis temukan letak persoalan terkait dengan budaya patriarki sangat menentukan kesetaraan gender di GKPB sangat kompleks. Oleh karena itu, salah satu hal yang dapat penulis sumbangkan bagi konteks tersebut ialah merekomendasi beberapa pendapat atau pandangan kepada pihak-pihak terkait dengan harapan agar persoalan ini bisa diselesaikan dengan bijaksana.

\section{Saran - Saran}

Kepada Lembaga Pendidikan Teologi dan Gereja (secara umum), antara lain: Pertama, bersama gereja, lembaga pendidikan teologi diharapkan memberi sumbangsih bagi teologi jemaat tentang peran perempuan pendeta, tidak hanya di jemaat, tetapi dalam jabatan-jabatan strategis dalam sinode gereja. Lembaga pendidikan teologi dan gereja bersinerji untuk membangun teologi jemaat dimaksud. Kedua, dalam rangka membuka ruang dan kesempatan kepada perempuan pendeta secara setara dan memungkinkan untuk berpatner dengan laki-laki dalam kepemimpinan gereja (di GKPB), maka lembaga pendidikan bersama gereja (dan lembaga adat) perlu melakukan seminar dan lokakarya untuk memperdalam wawasan dimaksud. SEMILOKA digelar dengan muatan tema tersebut dengan metode yang kreatif dan kontinyu.

Kepada GKPB secara khusus antara lain: Pertama, mencermati ekklesiologi GKPB yang belum teraplikasi dengan baik sampai saat ini, maka GKPB lewat tugas ini perlu lebih memperkaya ekklesiloginya dengan mempertimbangkan ekklesiologi feminis dari teolog feminis.
Kemudian, ekklesiologi GKPB yang dimiliki, semaksimal mungkin disosialisasikan kepada warga GKPB secara efektif dan efisien. Kedua, sinode GKPB diharapkan dapat merumuskan kebijakan gereja yang memberi ruang penerimaan dan apresiasi terhadap peran perempuan pendeta dalam jabatan strategis di sinode. Kebijakan gereja tidak hanya dirumuskan secara teoritik tetapi diwujudkan secara praktis dalam rumusan program secara struktural dari sinode, wilayah dan jemaat. Ketiga, GKPB secara lembaga dan persekutuan diharapkan berperan aktif untuk memberi wawasan transformatif kepada semua pelayan maupun warga gereja tentang kesadaran gender. Dalam program pembinaan, khotbah dan ibadah di GKPB mesti berbasis kesadaraan dan kesetaraan gender. Pembinaan holistik yang menyentuh semua warga gereja baik laki-laki maupun perempuan, anak maupun dewasa, pelayan/presbiter maupun umat secara menyeluruh. Tujuannya agar proses transformasi berlangsung secara utuh dan merata. Keempat, sistem kepemimpinan bergilir. Hal ini bertujuan agar perempuan pendeta mendapat pengalaman di jabatan strategis sinode, dan terjadinya regenerasi kepemimpinan yang adil gender/setara.

Kepada Pemerintahan Daerah Bali (yang di dalamnya pemerintahan Adat), antara lain: Pertama, pemerintah daerah harus membuat kebijakan (dan regulasi) daerah yang memungkinkan terbukanya peluang bagi perempuan dalam jabatan strategis di pemerintahan dan adat. Kedua, Lembaga adat mesti diberi wawasan kesadaran gender agar memberi transformasi pikiran dan praktis bagi komunitas masyarakat di Bali dan berdampak positif bagi gereja. Ketiga, bersama dengan semua unsur di masyarakat, pemerintah adat perlu memikirkan ulang 'awig-awig banjar' (aturanaturan desa adat di Bali) yang tidak memberikan kesempatan kepada perempuan untuk aktif sebagai peserta dalam rapat-rapat di dusun, desa.

Kepada Perempuan Pendeta antara lain:

Pertama, perempuan pendeta perlu untuk meningkatkan pendidikannya. Kedua, berperan aktif dalam kegiatan-kegiatan organisasi dalam skala-skala yang lebih besar. Ketiga, aktif dalam seminar-seminar atau pelatihan-pelatihan tentang kepemimpinan. Artinya bagaimana memperlengkapi diri lewat pelatihan dan pembekalan. Keempat, perempuan pendeta yang ditugaskan di jemaat-jemaat, sebagai jabatan strategis di tingkat jemaat, dalam menjalankan 
kepemimpinannya perlu untuk menunjukan gaya kepemimpinan yang berperspektif feminis.

\section{DAFTAR PUSTAKA}

\section{Buku-buku}

Barker, Chris. 2014. Kamus Kajian Budaya. Yogyakarta: Penerbit Kanisius

Budiawan. 2015. Media (Baru), Tubuh dan Ruang Publik.Yogyakarta:Jalasutra.

Denzin \& Lincoln. 2009. Handbook of Qualitative Research. Yogyakarta : Pustaka Pelajar

Eriyanto. 2003. Analisis Wacana : Pengantar Analisis Teks Media. Yogyakarta : LkiS Printing Cemerlang.

GKPB. 2007. Peraturan-Peraturan Gereja Kristen Protestan di Bali, Bali: Percetakan GKPB

GKPB. 2014. Tata Gereja Tahun 2014, Bali: Percetakan GKPB.

Lawalata Abraham, Justus. 2014. Tesis dengan Judul Perempuan pendeta dan jabatan strategis (Studi tentang Kepemimpinan Perempuan di Gereja Kristen Protestan di Bali dalam Perspektif Adil Gender).

Mies, Marla. 1986, Patriarchy and accumulation on a world Scale; Women in the International Division of Labour. Avon The Bath press.

Suparlan. 2010. Bahasa Dan Budaya. Yogyakarta: Intan Pariwara.
Tim Grasindo. 2017. UUD 1945 \& Amandemennya untuk Pelajar dan Umum. Jakarta: Grasindo.

Tim Penulis Sejarah GKPB. 2012. Dinamika GKPB Dalam Perjalanan Sejarah. Jakarta: PT BPK Gunung Mulia.

\section{Sumber Alkitab TB LAI}

\section{Sumber Internet}

https://www.qureta.com/post/perempuansebagai-pemimpin-negara-antarademokrasi-dan-agama, diakses pada 10 Desember 2018

http://id.wikipedia.org/wiki/Pemimpin_agama, diakses tanggal 10 Desember 2018

https://kbbi.web.id/representasi, diakses pada 2 Juli 2019.

http://www.pengertianmenurutparaahli.net/pen gertian-representasi/, diakses pada tanggal 2 Juli 2019

http://ekookdamezs.blogspot.com/2012/06/pen gertian-feminisme-dan-macammacam.html, diakses pada 2 Juli 2019

\section{Daftar Informan}

Made Kertiyana, kepala bidang administrasi dan kepegawaian GKPB, pada hari Rabu, 7 Agustus 2019 di Kantor Sinode GKPB, Mengwi Badung.

Justus Abraham Lawalata, Pendeta Jemaat GKPB Getsmani Denpasar, pada hari Jumat, 3 Mei 2019 di Pastori GKPB Getsemani Denpasar. 